\title{
Pembelajaran Interaktif Berbasis Articulate Storyline 3
}

\author{
Rianto $^{\mathrm{a}, 1}$ \\ ${ }^{a}$ IAIN Syekh Nurjati, Cirebon, Indonesia \\ ${ }^{1}$ riantompd@gmail.com

Article info ABSTRACT \\ Article history: \\ Received: 08-10-2020 \\ Revised : 15-11-2020 \\ Accepted: 02-12-2020 \\ This study aims to describe the making of interactive multimedia \\ independent learning applications based on articulate storyline 3. \\ The research method used is research and development or \\ Research and Development with a development model consisting \\ of five stages, namely analysis, design, development, \\ implementation, and evaluation. The results showed that the \\ feasibility level of a multimedia application based on articulate \\ storyline 3 which was named PERI GITA or digitalization \\ independent learning for interactive learning in the Digitalisasi \\ Pembelajaran Bahasa dan Sastra Indonesia was declared very \\ suitable for use as interactive multimedia learning.
}

Keywords:

articulate storyline digitalization

interactive learning

multimedia application

Penelitian ini bertujuan untuk mendeskripsikan pembuatan aplikasi multimedia interaktif pembelajaran mandiri berbasis articulate storyline 3. Metode penelitian yang digunakan adalah penelitian dan pengembangan atau Research and Development dengan model pengembangan yang terdiri dari lima tahap yaitu analisis, desain, pengembangan, implementasi, dan evaluasi. Hasil penelitian menunjukkan bahwa tingkat kelayakan aplikasi multimedia berbasis articulate storyline 3 yang diberi nama PERI GITA atau pembelajaran mandiri digitalisasi untuk pembelajaran interaktif pada mata kuliah Digitalisasi Pembelajaran Bahasa dan Sastra Indonesia dinyatakan sangat layak digunakan sebagai multimedia pembelajaran interaktif.

Copyright () 2020 Institut Agama Islam Negeri Syekh Nurjati Cirebon. All rights reserved.

\section{PENDAHULUAN}

Teknologi informasi saat ini semakin pesat menuju revolusi industri 5.0. Kemajuan teknologi ini berimplikasi pada dunia pendidikan yang semakin dituntut untuk menyelaraskan diri terhadap situasi dan kondisi. Pandemi Covid-19 yang terjadi saat ini tentunya harus disiasati dengan teknologi. Pembelajaran mandiri sebagai salah satu aspek proses dalam pendidikan menjadi satu hal terpenting. Hal ini sebagai penentu keberhasilan mahasiswa dalam menguasai materi yang sedang dipelajari. Dengan keadaan pandemi saat ini, perlu dilakukan sebuah inovasi multimedia pembelajaran interaktif sehingga pembelajaran lebih efektif.

Sistem pembelajaran jarak jauh yang digaungkan pemerintah melalui dinas pendidikan terkait, menjadi salah satu tantangan terbesar dalam proses pendidikan yang bertransformasi kepada pemanfaatan pembelajaran elektronik atau $e$ learning. Al-Ihwanah (2016) mengungkapkan selain dapat meningkatkan prestasi belajar mahasiswa, pembelajaran elektronik bertujuan juga untuk dapat melatih mahasiswa untuk lebih mandiri dalam mengembangkan soft skillnya. Untuk menjawab tantangan sistem pembelajaran jarak jauh yang sedang dilakukan saat 
ini adalah dengan cara memanfaatkan multimedia interaktif berbasis komputer. Multimedia interaktif yaitu kombinasi dari berbagai media dalam satu program dan memberi respon timbal balik bagi pengguna agar dapat melakukan berbagai kegiatan pembelajaran (Rafmana \& Chotimah, 2018). Pembelajaran yang interaktif memungkinkan siswa atau mahasiswa mudah memahami dan menyerap materi yang diajarkan (Yumini \& Rakhmawati, 2015).

Komputer memang dapat dikatakan selalu terikat dalam berbagai aspek pendidikan, termasuk proses pembelajaran. Proses pembelajaran yang biasanya hanya disampaikan tertulis dan secara ceramah atau lisan terkadang tidak diminati secara antusias oleh mahasiswa. Tentu disinilah peran media pembelajaran melalui komputer dapat digunakan. Media pembelajaran yang digunakan dalam proses belajar mengajar, dapat membangkitkan motivasi belajar, sebagai stimulus dalam kegiatan belajar, minat dan keinginan, serta membawa pengaruh-pengaruh psikologis terhadap siswa (Hamalik dalam Azhar, 2009; Purnama \& Asto B, 2014). Dalam proses belajar dan mengajar, peranan media pembelajaran merupakan satu kesatuan yang tidak dapat dipisahkan dari dunia pendidikan (Tafonao, 2018). Media adalah suatu wadah atau tempat yang memuat bahan yang akan disampaikan sesuai tujuan proses pembelajaran (Susilana \& Riyana, 2018; Hadza et al., 2020). Maka dapat dikatakan bahwa media pembelajaran merupakan alat yang digunakan dengan tujuan menyalurkan pesan pengirim kepada penerima, sehingga dapat merangsang minat, pikiran, perasaan, dan perhatian peserta didik atau mahasiswa untuk belajar lebih giat.

Komputer sebagai salah satu media pembelajaran memungkinkan mahasiswa mengalami proses belajar jauh lebih berkesan. Hal ini karena pembelajaran dengan dengan menggunakan komputer dapat menumbuhkan sikap mandiri dalam belajar (Rusman, 2012). Dalam menjalankan fungsinya, komputer sebagai media pembelajaran memiliki banyak fitur. Fitur tersebut dapat diterapkan dalam pembuatan media pembelajaran berbasis aplikasi perangkat lunak. Dari sekian banyak aplikasi, ada satu jenis aplikasi yang dapat digunakan dalam pembuatan multimedia interaktif, yaitu Articulate Storyline 3. Articulate Storyline 3 merupakan topik baru sehingga mahasiswa belum mengenal program tersebut. Namun, Articulate Storyline 3 juga memiliki beberapa fitur yang mirip dengan power point (Yahya et al., 2020). Aplikasi ini memang masih jarang digunakan dalam pembuatan multimedia karena membutuhkan spesifikasi komputer yang mumpuni dalam menjalankannya. Namun, dibalik kekurangannya terdapat kelebihan berupa kemudahan fungsi trigger atau navigasi tombol tanpa perlu pengkodean yang sulit. Dapat dikatakan bisa dilakukan oleh pemula yang ingin belajar dalam membuat aplikasi ini.

Mata kuliah Digitalisasi Pembelajaran Bahasa dan Sastra Indonesia merupakan mata kuliah baru untuk menjawab pembelajaran di era digital terlebih saat pandemi melanda. Mata kuliah ini dapat memberikan kesempatan kepada mahasiswa untuk mengeksplorasi transformasi media pembelajaran secara digital. Maka sangatlah tepat jika pembelajaran digitalisasi menggunakan sebuah software yang mampu dikembangkan menjadi multimedia pembelajaran secara interaktif. Pembelajaran menggunakan multimedia pada hakikatnya merupakan pembelajaran dengan tujuan mengoptimalkan semua aktivitas otak selama peserta didik atau mahasiswa melakukan aktivitas pembelajaran (Darmawan, 2012). Selaras dengan hal itu, media pembelajaran interaktif ini mampu membuat mahasiswa lebih aktif dan memiliki motivasi tinggi dalam belajar. Hal ini karena 
media pembelajaran ini mampu menampilkan teks, gambar, audio, video, serta animasi-animasi lainnya (Rohmah \& Bukhori, 2020)

Maka dalam penelitian ini dikembangkan sebuah aplikasi multimedia interaktif yang dibuat untuk pembelajaran jarak jauh pada mata kuliah Digitalisasi Pembelajaran Bahasa dan Sastra Indonesia di Jurusan Tadris Bahasa Indonesia FITK-IAIN Syekh Nurjati Cirebon. Materi pertama dalam mata kuliah ini adalah tentang hakikat dan fungsi digitalisasi pembelajaran. Aplikasi ini diberi nama Peri Gita yang merupakan kependekan dari pembelajaran mandiri digitalisasi.

\section{METODE}

Penelitian pengembangan multimedia interaktif berbasis articulate storyline 3 ini merujuk pada Research and Development $(R \& D)$ model $A D D I E$, yang terdiri lima tahap yaitu Analisis (Analysis), Perancangan (Design), Pengembangan (Development), Implementasi (Implemetation), serta Evaluasi (Evaluation). Tujuan jenis penelitian ini adalah menghasilkan media baru melalui proses pengembangan (Mulyatiningsih, 2011; Izzati \& Sumarsih, 2017). Pada tahap analisis, langkah yang dilakukan berupa menganalisis software yang digunakan untuk membuat multimedia interaktif pembelajaran, yaitu software Articulate Storyline 3.

Tahap perencanaan berupa: a) merancang angket evaluasi sebagai instrumen penelitian. Angket ini diisi oleh dosen sebagai praktisi pembelajaran, ahli media pembelajaran, serta respon mahasiswa, dan b) menyusun flowchart, atau diagram alir aplikasi ini sesuai desain pembelajaran submateri pertemuan pertama, yaitu tentang hakikat dan fungsi digitalisasi pembelajaran. Tahap ketiga berupa pengembangan. Langkah yang dilakukan pada tahap pengembangan terdiri atas: a) validasi aplikasi multimedia pembelajaran interaktif kepada ahli media dan praktisi pembelajaran atau dosen, dan b) revisi aplikasi multimedia pembelajaran interaktif yang mengacu pada ahli media pembelajaran dan dosen sebagai praktisi pembelajaran.

Tahap implementasi, meliputi: a) uji coba aplikasi kepada mahasiswa yang dilakukan secara daring karena sedang menerapkan sistem pembelajaran jarak jauh, b) pengambilan data berupa angket respon mahasiswa dan dosen, serta c) melakukan analisis data hasil angket penilaian dosen mata kuliah digitalisasi pembelajaran dan hasil respon mahasiswa. Tahap evaluasi merupakan evaluasi terhadap kualitas produk setelah uji coba lapangan. Hasil evaluasi diperoleh dari lembar angket respon mahasiswa. Evaluasi dilakukan untuk perbaikan produk yang dikembangkan menjadi produk akhir.

Data yang dikumpulkan dalam penelitian ini terdiri atas dua jenis data, yaitu data kuantitatif dan kualitatif. Data kuantitatif yaitu data berupa penilaian tentang media pembelajaran aplikasi multimedia interaktif dari ahli media pembelajaran, dosen sebagai praktisi pembelajaran serta respon mahasiswa. Data kualitatif yaitu data proses pengembangan media pembelajaran berbasis articulate storyline 3, berupa saran dari ahli media pembelajaran, dosen sebagai praktisi pembelajaran dan mahasiswa. 
Tabel 1. Penilaian Kualitatif menjadi Kuantitatif

\begin{tabular}{cc}
\hline Kategori & Skor \\
\hline Sangat Baik & 5 \\
Baik & 4 \\
Cukup & 3 \\
Kurang & 2 \\
Sangat Kurang & 1 \\
\hline
\end{tabular}

Setelah diperoleh data, maka tahap berikutnya adalah analisis. Data hasil penilaian kualitas multimedia interaktif pembelajaran berbasis articulate storyline 3 diperoleh dari hasil angket oleh ahli media pembelajaran, praktisi pembelajaran dosen mata kuliah Digitalisasi Pembelajaran Bahasa dan Sastra Indonesia. Selanjutnya data diproses melalui tahapan: a) mengubah data penilaian kualitatif menjadi data kuantitatif, adapun ketentuannya dapat dilihat pada Tabel 1, b) menghitung rata-rata skor setiap indikator dengan rumus dari Riduwan \& Sunarto, 2015; (Fatia \& Ariani, 2020), c) menginterpretasikan secara kualitatif jumlah ratarata skor setiap aspek, seperti pada Tabel 2, dan d) menganalisis respon mahasiswa dengan skala Guttman, seperti pada Tabel 3.

Tabel 2. Penilaian Kuantitatif menjadi Kualitatif

\begin{tabular}{lll}
\hline Skor & Interval & Kategori \\
\hline 5 & $\mathrm{X}>4.21$ & Sangat Layak \\
4 & $3.40 \leq \mathrm{X} \leq 4.21$ & Layak \\
3 & $2.60 \leq \mathrm{X} \leq 3.40$ & Cukup Layak \\
2 & $1.79 \leq \mathrm{X} \leq 2.60$ & Kurang Layak \\
1 & $\mathrm{X} \leq 1.79$ & Sangat Tidak Layak \\
\hline
\end{tabular}

Jawaban dari angket respon mahasiswa akan menggunakan angket skala Guttman. Tampilan skala Guttman pada Tabel 3.

Tabel 3. Kategori Penilaian Pada Skala Guttman

\begin{tabular}{ccc}
\hline No & Skor & Keterangan \\
\hline 1 & 0 & Ya \\
2 & 1 & Tidak \\
\hline
\end{tabular}

Adapun kriteria skor dari respon mahasiswa dapat dilihat pada Tabel 4.

Tabel 4. Kriteria Skor Angket Respon Mahasiswa

\begin{tabular}{ccc}
\hline No & Skor & Keterangan \\
\hline 1 & $85-100 \%$ & Sangat Baik \\
2 & $70-84 \%$ & Baik \\
3 & $55-69 \%$ & Cukup \\
4 & $40-54 \%$ & Kurang \\
5 & $0-39 \%$ & Sangat Kurang \\
\hline
\end{tabular}

\section{HASIL DAN PEMBAHASAN}

Prosedur penelitian dan pengembangan ini diadaptasi dari rangkuman aktivitas model ADDIE yang akan dijelaskan sebagai berikut.

\section{Analisis (Analysis)}

Pada Tahap ini yaitu analisis terhadap software Articulate Storyline 3. Tahap ini penting untuk mengetahui spesifikasi syarat penggunaan software dan fungsifungsi dari setiap menu yang dimiliki software ini. Penggunaan software ini seperti layaknya membuat pembelajaran power point namun dikombinasikan dengan fungsi trigger tanpa pengkodean yang mudah digunakan untuk 
memfungsikan tombol-tombol navigasi. Ada beberapa syarat yang harus dipenuhi untuk melakukan penginstalan aplikasi Articulate Storyline 3 pada komputer, yaitu: pertama, perangkat keras yang terdiri: a) $\mathrm{CPU} 2 \mathrm{GHz}$ processor or higher (32-bit or 64-bit), b) memori minimal 2 GB, c) Available disk space minimal 1 $\mathrm{GB}, \mathrm{d})$ display $1280 \times 720$ screen resolution or higher, dan e) kartu multimedia, pelantang, kamera web untuk merekam suara dan video 2 . Kedua, perangkat lunak yang terdiri: a) operasi sistem windows 7, 8, atau 10 (32-bit atau 64-bit), b) Mac $O S \times 10.6 .8$, c) netframework minimal versi 4.5.2, d) visual++, serta e) Adobe flash player minimal versi 10.3 (Rohmah \& Bukhori, 2020).

\section{Perancangan (Design)}

Pada tahap ini yang dilakukan beberapa perancangan, seperti: a) menyusun instrumen penelitian berupa angket evaluasi multimedia pembelajaran interaktif oleh ahli media dan dosen sebagai praktisi pembelajaran serta angket respon mahasiswa. Karena pembelajaran menggunakan sistem pembelajaran jarak jauh maka untuk respon mahasiswa menggunakan fasilitas google form, serta b) menyusun flowchart atau diagram alir dan desain aplikasi ini sesuai desain pembelajaran sub materi pertemuan pertama yaitu tentang hakikat dan urgensi digitalisasi pembelajaran. Gambar 1 merupakan wujud dari di diagram alir yang dimaksud.

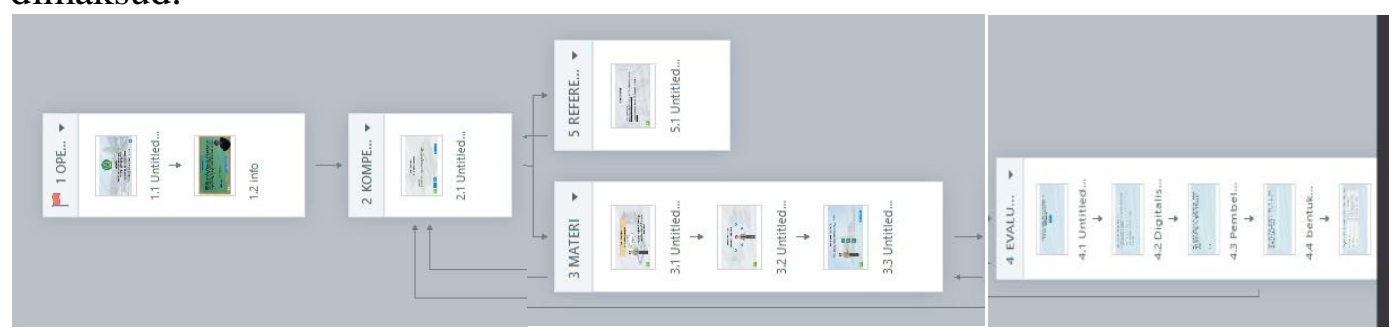

Gambar 1. Diagram Alir

Gambar 2 dan 3 menunjukkan tampilan awal aplikasi PERI GITA. Tampilan awal pada gambar 2 memuat identitas nama aplikasi, mata kuliah dan institusi. Tampilan awal layaknya sebuah perkenalan yang memuat informasi tentang aplikasi serta nama dan foto pengembang aplikasi dapat dilihat pada gambar 3 . Kedua tampilan baik gambar 2 dan gambar 3 memiliki latar musik singkat sebagai pembuka aplikasi.

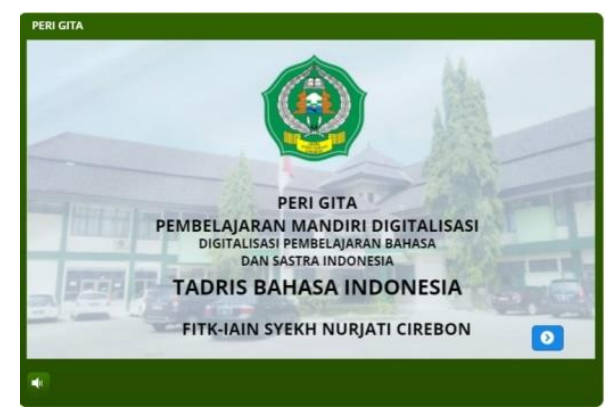

Gambar 2. Tampilan Awal

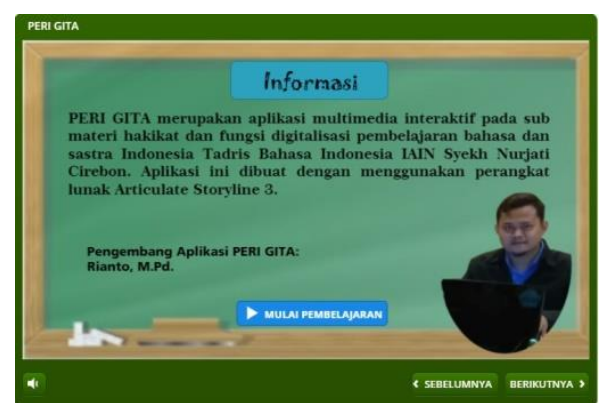

Gambar 3. Tampilan Informasi

Selanjutnya mahasiswa diarahkan mengeklik tombol mulai pembelajaran pada gambar 3. Maka muncul gambar 4 yang merupakan penyampaian kompetensi dasar materi kepada mahasiswa sebagai pengguna aplikasi. Setelah membaca kompetensi yang akan dicapai, mahasiswa akan mengeklik tombol materi. Maka 
akan muncul layar berikutnya berupa karakter guru yang mempertanyakan apa pengertian digitalisasi pembelajaran dan muncul dibawah teks pertanyaan tersebut adalah jawaban dari pertanyaan itu. Terlihat pada gambar 4.

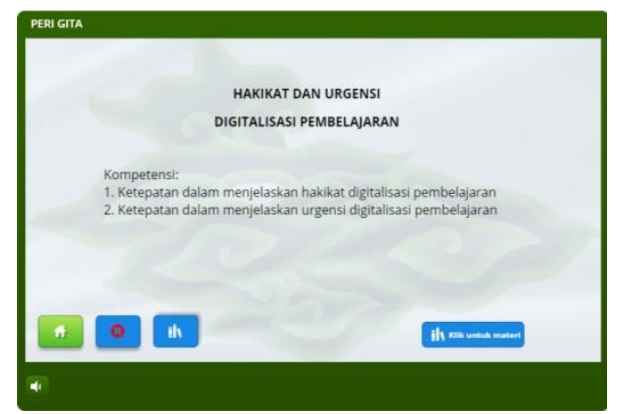

Gambar 4. Kompetensi pembelajaran

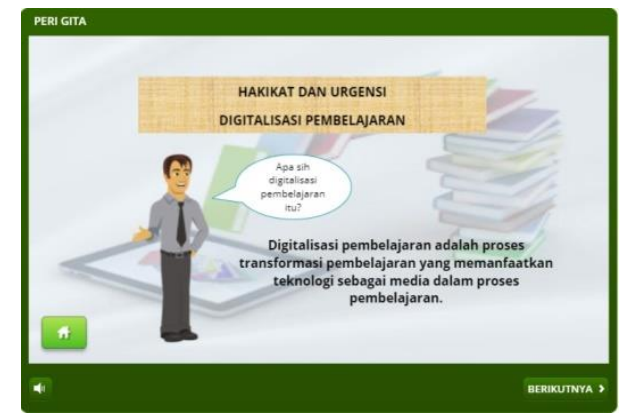

Gambar 5. Pengertian Digitalisasi

Ketika mahasiswa mengeklik selanjutnya maka muncul layar karakter guru yang menghadap ke arah depan. Pada layar ini (gambar 6) telah diberi empat fungsi marker, yaitu ketika tetikus diarahkan ke empat simbol itu secara otomatis akan muncul judul sub materi yang akan disampaikan. Sebagai contoh pada gambar 7 tampak video proses pembelajaran digital dengan durasi tiga menit.

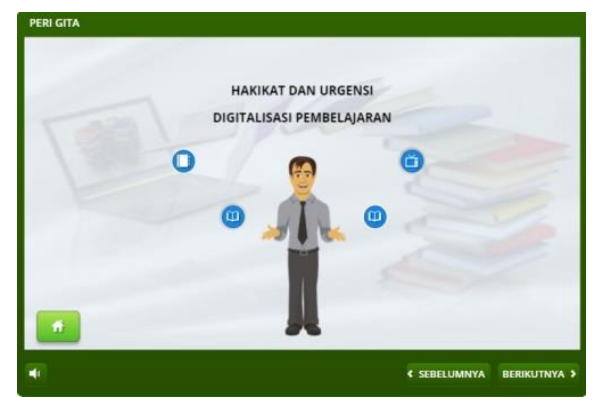

Gambar 6. Fungsi Tombol Marker

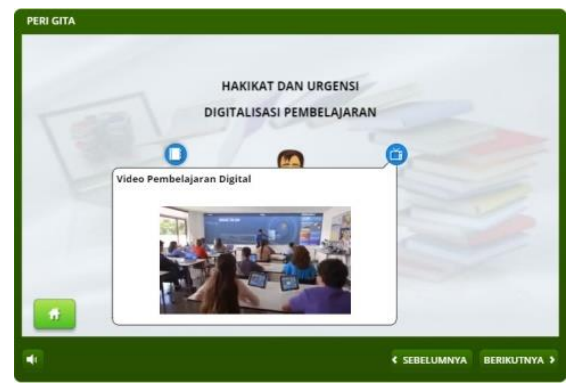

Gambar 7. Tombol Video

Setelah isi keempat tombol marker dibaca dan disimak oleh mahasiswa, langkah selanjutnya adalah mengeklik tombol selanjutnya. Maka akan muncul layar selanjutnya (gambar 8) yaitu fungsi hotspot. Pada layar gambar 8 ketika mahasiswa menggunakan tetikusnya mengarah ke tombol 1 dan tombol 2 maka akan muncul secara otomatis gambar suasana pembelajaran menggunakan gawai di kelas serta pengertian mobile learning, dapat dilihat pada gambar 9. Pada tombol 3 berisi sebuah rekaman audio pembacaan pengertian game based learning.

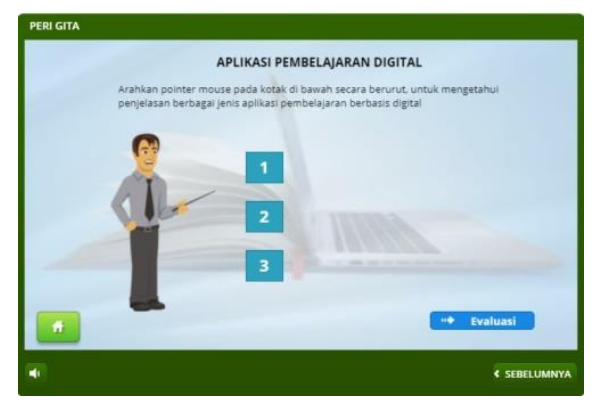

Gambar 8. Fungsi Tombol Hotspot

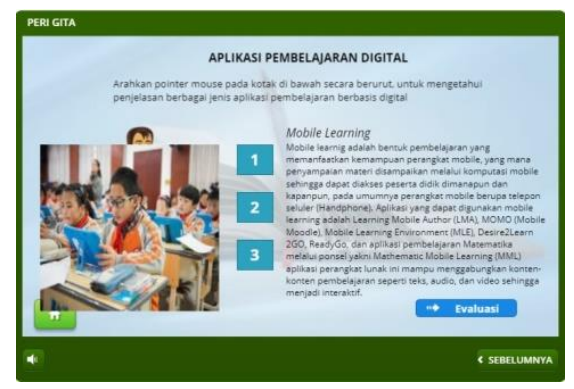

Gambar 9. Penggunaan Hotspot 
Tahap terakhir dari pembelajaran menggunakan aplikasi ini adalah evaluasi. Pada evaluasi diberikan soal pilihan ganda sebanyak lima soal. Salah satunya dapat dilihat pada gambar 10. Penyelesaian soal diberi waktu selama sepuluh menit, penghitung waktu tampak seperti pada sudut kanan atas gambar 10. Setelah mengerjakan tes evaluasi akan muncul secara otomatis skor yang diperoleh mahasiswa seperti tampak pada gambar 10. Mahasiswa boleh mengulang tes evaluasi apabila nilai masih di bawah batas nilai.

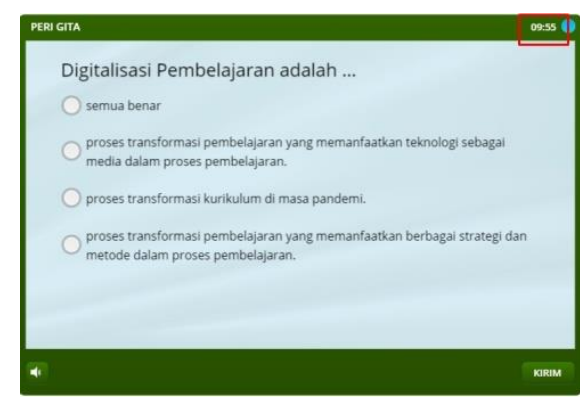

Gambar 10. Evaluasi Pilihan Ganda

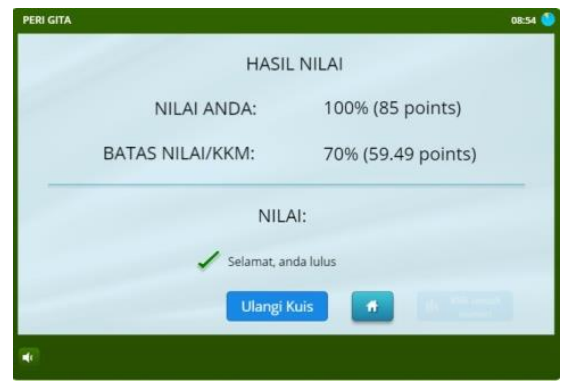

Gambar 11. Hasil Evaluasi

\section{Pengembangan (Development)}

Pada tahap ini yang dilakukan beberapa tahapan pengembangan, yaitu validasi dari ahli media oleh dosen bidang TIK bernama Agus Pamuji, M.Kom.

Tabel 5. Hasil Validasi Ahli Media Pembelajaran

\begin{tabular}{clccc}
\hline No & Aspek Penilaian & Jumlah Nilai & Rata-rata Nilai & Kategori \\
\hline $\mathbf{1}$ & Perangkat Lunak & 40 & 4,44 & Sangat Layak \\
$\mathbf{2}$ & Desain Pembelajaran & 38 & 4,75 & Sangat Layak \\
$\mathbf{3}$ & Komunikasi visual & 27 & 4,5 & Sangat Layak \\
& Total & $\mathbf{1 0 5}$ & $\mathbf{4 , 3 5}$ & Sangat Layak \\
\hline
\end{tabular}

Berdasarkan tabel di atas, diperoleh data yang ditinjau dari aspek perangkat lunak, desain pembelajaran serta komunikasi visual, nilai yang diperoleh dengan rata-rata 4,35 yang termasuk dalam kategori sangat layak. Hasil penilaian dari ketiga aspek masuk dalam rentang nilai $X>4,2$ sehingga tingkat kelayakan media pembelajaran aplikasi PERI GITA atau aplikasi pembelajaran mandiri digitalisasi pembelajaran berdasarkan penilaian validasi oleh ahli media termasuk ke dalam kategori sangat layak. Berdasarkan saran atau pendapat dari ahli media, dilakukan revisi hanya pada butir nomor 1 dan nomor 18 untuk membuat aplikasi PERI GITA menjadi lebih baik, yaitu menambah tombol navigasi menuju Home dan mengecilkan latar suara pada slide materi.

Tahap selanjutnya adalah validasi oleh praktisi pembelajaran, yaitu dosen mata kuliah Digitalisasi Pembelajaran Bahasa dan Sastra Indonesia bernama Veni Nurpadillah, M.Pd. Hasil dari validasi ditunjukkan pada Tabel 6.

Tabel 6. Hasil Validasi Praktisi Pembelajaran

\begin{tabular}{clccc}
\hline No & \multicolumn{1}{c}{ Aspek Penilaian } & Jumlah Nilai & Rata-rata Nilai & Kategori \\
\hline 1 & Perangkat Lunak & 22 & 4,4 & Sangat Layak \\
2 & Desain Pembelajaran & 40 & 4,44 & Sangat Layak \\
3 & Komunikasi visual & 27 & 4,33 & Sangat Layak \\
& Total & 91 & 4,39 & Sangat Layak \\
\hline
\end{tabular}


Berdasarkan Tabel 6 diperoleh data bahwa ditinjau dari aspek rekayasa perangkat lunak, desain pembelajaran dan komunikasi visual diperoleh hasil penilaian dengan nilai rata-rata 4,39 yang termasuk dalam kategori sangat layak. Hasil penilaian dari ketiga aspek masuk dalam rentang nilai $X>4,2$ sehingga tingkat kelayakan media pembelajaran interaktif PERI GITA berdasarkan validasi oleh praktisi media pembelajaran masuk ke dalam kategori Sangat Layak. Berdasarkan saran dari praktisi pembelajaran, pada uraian materi harus dipaparkan secara rinci sehingga mahasiswa mudah memahami pembelajaran. Pada revisi bagian tersebut peneliti memperjelas dengan menambahkan contoh gambar materi pada suasana pembelajaran secara digital.

\section{Implementasi (Implementation)}

Hasil respon mahasiswa terhadap aplikasi PERI GITA yang dilakukan secara daring pada kelas B semester 4 sebanyak 34 mahasiswa. Hasilnya dapat diketahui bahwa seluruh pertanyaan mendapatkan "Respon Positif" dengan persentase 87 $\%$.

\section{Evaluasi (Evaluation)}

Tahap ini merupakan evaluasi terhadap kualitas produk setelah uji coba lapangan. Hasil evaluasi diperoleh dari lembar angket respon mahasiswa. Evaluasi dilakukan untuk perbaikan produk yang dikembangkan menjadi produk akhir. Pada tahap ini tidak ada perbaikan karena respon mahasiswa sudah positif.

\section{SIMPULAN}

Berdasarkan analisis data dan pembahasan, maka dapat disimpulkan. Pengembangan aplikasi multimedia interaktif PERI GITA pada mata kuliah digitalisasi pembelajaran bahasa dan sastra Indonesia menggunakan model pengembangan model $A D D I E$, dinyatakan sangat layak. Kelayakan aplikasi ini berdasarkan penilaian keseluruhan aspek validasi ahli media pembelajaran, praktisi pembelajaran, serta respon mahasiswa memperoleh kategori sangat layak digunakan pada mata kuliah digitalisasi pembelajaran bahasa dan sastra Indonesia.

\section{DAFTAR PUSTAKA}

Al-Ihwanah, A.-I. (2016). Implementasi E-Learning Dalam Kegiatan Pembelajaran PGMI IAIN Sulthan Thaha Saifuddin Jambi. Cakrawala: Jurnal Studi Islam, 11(1), 76-91.

Darmawan, D. (2012). Inovasi Pendidikan. Bandung: Rosda Karya.

Fatia, I., \& Ariani, Y. (2020). Pengembangan Media Articulate Storyline 3 pada Pembelajaran Faktor dan Kelipatan Suatu Bilangan di Kelas IV Sekolah Dasar. 3(2), 503-511.

Hadza, C., Sesrita, A., \& Suherman, I. (2020). Development of Learning Media Based on Articulate Storyline. Indonesian Journal of Applied Research (IJAR), 1(2), 80-85. https://doi.org/10.30997/ijar.v1i2.54

Izzati, F. D., \& Sumarsih. (2017). Pengembangan Media Pembelajaran Aplikasi Peta Akuntansi (TAKSI) Berbasis Android Pada Materi Siklus Akuntansi Perusahaan Jasa Development of Learning Media Using Android-Based Application Peta Akuntansi (Taksi) on Accounting Cycle of Service Enterpris. Jurnal Pendidikan Akuntansi Indonesia, XV(2), 32-46.

Purnama, S., \& Asto B, I. G. P. (2014). Pengembangan Media Pembelajaran Interaktif Menggunakan Software Articulate Storyline Pada Mata Pelajaran Teknik Elektronika Dasar Kelas X TEI 1 Di SMK Negeri 2 Probolinggo. 


\section{Indonesian Language Education and Literature e-ISSN: 2502-2261 \\ http://www.syekhnurjati.ac.id/jurnal/index.php/jeill/ \\ Vol. 6, No. 1, Desember 2020, 84 - 92}

Jurnal Pendidikan Teknik Elektro, 3(2), 275-279.

Rafmana, H., \& Chotimah, U. (2018). Pengembangan Multimedia Interaktif Berbasis Articulate Storyline untuk Meningkatkan Motivasi Belajar Siswa Pada Mata Pelajaran PKn Kelas XI di SMA Srijaya Negara Palembang. Jurnal Bhinneka Tunggal Ika, 05(1), 52-65.

Rohmah, F. N., \& Bukhori, I. (2020). Pengembangan Media Pembelajaran Interaktif Mata Pelajaran Korespondensi Berbasis Android Menggunakan Articulate Storyline 3. Ecoducation: Economic and Education Journal, 2(2), 169-182.

Rusman. (2012). Belajar dan Pembelajaran Berbasis Komputer: Mengembangkan Profesionalisme Guru Abad 21. Bandung: Alfabeta.

Tafonao, T. (2018). Peranan Media Pembelajaran dalam Meningkatkan Minat Belajar Mahasiswa. Jurnal Komunikasi Pendidikan, 2(2), 103-113.

Yahya, R., Ummah, S. K., \& Effendi, M. M. (2020). Pengembangan Perangkat Pembelajaran Flipped Classroom Bercirikan SJME (Supremum Journal of Mathemathics Education), 4(1), 78-91.

Yumini, S., \& Rakhmawati, L. (2015). Pengembangan Media Pembelajaran Interaktif Berbasis Articulate Storyline pada Mata Diklat Teknik Elektronika Dasar di SMK Negeri 1 Jetis Mojokerto. Jurnal Pendidikan Teknik Elektro, 4(3), 845-849. 